\title{
STUDI KASUS PENYUSUTAN ARSIP DI UNIVERSITAS NEGERI SEMARANG
}

\author{
Ahmad Saeroji, Agung Kuswantoro, Ratu Bunga Maremitha Ungu, Ade Rustiana \\ Fakultas Ekonomi,Universitas Negeri Semarang Indonesia \\ saeroji@mail.unnes.ac.id, agungbinmadik@gmail.com, ratubunga@mail.unnes.ac.id, aderustiana68@yahoo.co.id
}

\begin{abstract}
Abstrak: Studi Kasus Penyusutan Arsip di Universitas Negeri Semarang. Tujuan dari penelitian ini adalah (1) Untuk mengetahui penyusutan arsip secara peraturan perundang-undangan, (2) Untuk mengetahui cara penyusutan arsip di Universitas Negeri Semarang, (3) Untuk mengetahui prosedur penyusutan arsip di Universitas Negeri Semarang. Metode yang digunakan dalam penelitian ini adalah studi kasus, dimana peneliti menyelidiki secara cermat suatu program, peristiwa, aktivitas, proses atau sekelompok individu. Penyusutan arsip di lingkungan Universitas Negeri Semarang menggunakan prosedur penyusutan arsip menurut UU No. 43 Tahun 2009 Tentang Kearsipan, diantaranya (a) Pemindahan Arsip Inaktif dari unit pengolah ke unit kearsipan. (b) Pemusnahan arsip yang telah habis masa retensinya dan tidak memiliki nilai guna dilaksanakan sesuai dengan ketentuan peraturan perundang-undangan. (c) Penyerahan arsip statis oleh pencipta arsip kepada lembaga kearsipan. Cara penyerahan arsip dari unit kerja ke lembaga kearsipan Universitas Negeri Semarang meliputi (a) Melalukan pemeriksaan dan penilaian arsip yang akan diserahkan, (b) Pembuatan Daftar Arsip yang akan diserahkan ke UPT Kearsipan, (c) Pembuatan berita acara serah terima arsip, (d) Pelaksanaan penyerahan arsip. Prosedur penyusutan arsip di Universitas Negeri Semarang adalah Pembuatan Daftar Pertelaan Arsip, Pemindahan Arsip, Pemusnahan Arsip yang sudah tidak bernilai guna, dan Penyerahan arsip ke UPT Kearsipan yang bernilai guna permanen/ sejarah.
\end{abstract}

Kata Kunci: Penyusutan, Arsip, Prosedur.

\begin{abstract}
Case Study of Archive Depreciation at Universitas Negeri Semarang. The purpose of this study is (1) To find out the depreciation of the archive by statutory regulations, (2) To find out how to shrink the archive at Universitas Negeri Semarang, (3) To find out the procedure of shrinkage of records at Universitas Negeri Semarang. The method used in this research is a case study, where researchers investigate carefully a program, event, activity, process or group of individuals. Depreciation of records in the Universitas Negeri Semarang environment uses the procedure of depreciation of records according to Law No. 43 of 2009 concerning Archives, including (a) Transfer of Inactive Records from the processing unit to the filing unit. (b) Destruction of archives that have retired and which do not have a value for use are carried out in accordance with statutory provisions. (c) Submission of a static archive by the creator of the archive to the archival institution. How to submit archives from work units to the archives institute of Universitas Negeri Semarang include (a) Conducting examination and evaluation of archives to be submitted, (b) Making Archive List to be submitted to the UPT Kearsipan, (c) Preparation of minutes of archive handover, (d) ) Implementation of submission of archives. The procedure of depreciation of records at Universitas Negeri Semarang is the Making of Archive Information Archives list, Transfer of Archives, Destruction of Archives that have no use value, and Submission of archives to UPT Kearsipan that are of permanent / historical value.
\end{abstract}

Keyword: Depreciation, Archive, Procedure.

\section{PENDAHULUAN}

Arsip tercipta dari kegiatan suatu organisasi atau lembaga. Arsip tersebut akan digunakan sebagai arsip aktif dalam penyelenggaraan administrasi negara atau pemerintah dan juga perguruan tinggi. Menurut Barthos (2007:3) mengatakan bahwa manfaat arsip adalah membantu daya ingatan manusia dan merupakan salah satu bahan untuk penelitian ilmiah. Arsip yang tercipta dari unit pengolahan akan selalu mengalami peningkatan, karena kegiatan suatu lembaga atau individu tidak pernah 
terhenti dan akan semakin berkembang. Hal ini disebabkan oleh perkembangan zaman yang semakin maju.

Sedangkan Menurut Sulistyo (1996:13) mengatakan bahwa :

"Arsip itu sendiri mempunyai fungsi sebagai informasi terekam yang dihasilkan oleh suatu instansi, lembaga, organisasi, perorangan yang juga mempunyai banyak fungsi untuk membantu pengambilan keputusan, menunjang perencanaan, mendukung pengawasan sebagai barang bukti, memori perusahaan, melestarikan kegiatan lembaga atau instansi, menyediakan informasi produk, sebagai rujukan historis, menyediakan informasi personalia keuangan dan sejenisnya, memelihara aktivitas hubungan masyarakat, arsip juga digunakan untuk hubungan politik, untuk pendidikan, untuk menyelamatkan diri baik secara fisik maupun rohani, dan untuk menelur istilah".

Arsip aktif di unit pengolah kemudian dipindahkan ke unit kearsipan dan akan menjadi arsip inaktif melalui proses penyusutan arsip. Arsip yang ada di unit kearsipan semakin lama akan bertambah dan menumpuk sehingga terjadi penumpukan arsip. Arsip yang menumpuk tersebut adalah arsip inaktif yang belum disusutkan. Menurut Barthos (2007:4), arsip inaktif adalah arsip yang tidak secara langsung dan tidak terus menerus diperlukan dan digunakan dalam penyelenggaraan administrasi sehari-sehari serta dikelola oleh pusat arsip. Penyusutan arsip bertujuan untuk mengurangi jumlah dan nilai guna arsip yang ada di unit kerja dan unit kearsipan.

Penyusutan arsip merupakan salah satu kegiatan pengelolaan arsip inaktif di unit kearsipan. Sudjono (2007:6) berpendapat bahwa:

"Penyusutan arsip adalah upaya untuk mengurangi jumlah arsip yang tercipta dalam suatu organisasi. Artinya adalah menetapkan mana arsip yang dipindahkan dan yang dimusnahkan. Proses penyusutan arsip akan berjalan dengan lancar apabila dilakukan melalui prosedur yang baik dan fasilitas yang mendukung".

Dalam penyusutan arsip inaktif di Universitas Negeri Semarang terdapat berbagai masalah yang menyebabkan terjadinya penumpukan arsip, baik di unit pengolah ataupun di unit kearsipan. Arsiparsip yang menumpuk tersebut menjadi sumber masalah karena akan memakan tempat dan biaya untuk perawatannya. sementara arsip tersebut sudah memasuki masa inaktif.

Selain itu, banyaknya arsip yang menumpuk maka akan semakin sulit dalam penataan dan pencarian arsip kembali sehingga mengakibatkan tidak efektifnya penggunaan arsip-arsip yang ada yang masih memiliki nilai guna tinggi. Penumpukan arsip juga terjadi karena prosedur penyusutan arsip yang kurang sesuai dengan standar operating procedure (SOP) yang ada. Jika melakukan penyusutan arsip dengan tidak berdasarkan prosedur maka akan terjadi kekacauan dalam pengelolaan arsip, yaitu ketika melakukan penyusutan, pemusnahan dan pemeliharaan arsip (Annisa,2013). 
Sudjono (2007:74) mengatakan bahwa menyusutkan arsip dapat dilakukan dengan cara sebagai berikut:

1) Pemeriksaan arsip, yaitu pemeriksaan susunan arsip dan jadwal retensi arsip, pemeriksaan dilakukan untuk mengetahui apakah arsiparsip tersebut benar-benar telah habis jangka simpannya dengan berpedoman pada jadwal retensi arsip.

2) Pendaftaran, arsip yang telah diperiksa sebagai arsip yang diusul musnah harus dibuat daftarnya, sehingga dari daftar ini diketahui secara jelas informasi tentang arsip yang akan dimusnahkan.

3) Pembentukan panitia pemusnahan, pembentukan panitia dilaksanakan jika arsip yang akan dimusnahkan memiliki retensi sebuluh tahun atau lebih. Jika arsip yang akan dimusnahkan memiliki retensi dibawah sepuluh tahun, maka tidak perlu dibuat kepanitiaan, cukup dilaksanakan oleh unit yang secara fungsional bertugas mengelola arsip. Susunan kepanitiaan sebaiknya terdiri dari ketua, sekretaris, dan anggota dengan jumlah sesuai kebutuhan instansi, untuk arsip yang retensinya sudah melewati sepuluh tahun sebaiknya panitia terdiri dari unit pengelola arsip, unit pengawasan, unit hukum, dan unit-unit terkait lainnya.

4) Persetujuan atau pengesahan, arsip yang memiliki retensi dibawah sepuluh tahun, kiranya cukup dilaksanakan oleh instansi pemilik arsip. Kemudian disahkan oleh pemimpin organisasi untuk dilaksanakan pemusnahan. Namun untuk arsip yang memiliki retensi sepuluh tahun keatas, khususnya untuk instansi pemerintah harus melalui persetujuan Arsip Nasional RI, karena arsip yang memiliki retensi di atas sepuluh tahun kemungkinan lebih besar memiliki nilai sekunder.

5) Pembuatan berita acara, berita acara pemusnahan arsip dapat menjadi dasar hukum bahwa pelaksanaan pemusnahan arsip dilakukan secara sah, dan juga berfungsi sebagai pengganti arsip yang dimusnahkan.

6) Pelaksanaan pemusnahan, pemusnahan arsip dapat dilakukan dengan cara dibakar, dicacah, atau dibuat bubur kertas, yang penting fisik dan informasinya tidak dapat dikenali lagi. Kemudian dalam pelaksanaan pemusnahan arsip perlu disaksikan minimal oleh dua orang pejabat dari bidang hukum atau perundang-undangan atau bidang pengawas yang nantinya akan menandatangani berita acara sebagai saksi pemusnahan.

Sedangkan menurut Widodo (2009:39) berpendapat bahwa prosedur penyusutan nilai guna arsip dilakukan ketika frekuensi kegunaan arsip sudah mulai berkurang atau sudah tidak memiliki nilai guna sama sekali bagi lembaga pencipta arsip.

Hal lain yang perlu diperhatikan pula dalam proses penilaian arsip menurut Sudjono (2007:29) adalah:

1) Memperhatikan hubungan antara berkas yang satu dengan yang lain.

2) Penilaian berdasarkan kegiatan dokumentasi organisasi yang bersangkutan 
3) Memperhatikan arti dari sumber arsip yang menciptakan dan memperhatikan kedudukan masing-masing unit organisasi, struktur pemerintahan dan kegiatannya.

4) Memperhitungkan biaya pemeliharaannya.

Berdasarkan beberapa keterangan diatas dapat disimpulkan bahwa sangat pentingnya penyusutan arsip sesuai dengan prosedur yang benar. Penyusutan arsip menurut Susan Z Diamond dalam Irawan (2009:22) dapat dilakukan dengan tahapan berikut ini:

1) Inventaris, yakni menentukan arsip apa yang dimiliki suatu instansi, di mana, berapa banyak, dan sebagainya.

2) Penilaian arsip, menentukan nilai guna arsip.

3) Penyiapan Jadwal Retensi Arsip (JRA).

4) Pelaksanaan dan pengendalian.

Pengertian Arsip adalah naskah-naskah yang dibuat dan diterima oleh lembaga-lembaga dan badan-badan pemerintahan dalam bentuk corak apapun, baik dalam keadaan tunggal maupun berkelompok dalam rangka pelaksanaan kegiatan pemerintahan (Amsyah, 2003:65). Sedangkan menurut Barthos (2007:1) Arsip (record) yang dalam istilah bahasa Indonesia ada yang menyebutkan “warkat", pada pokoknya dapat diberikan pengertian sebagai : setiap catatan tertulis baik dalam bentuk gambaran ataupun bagan yang memuat keterangan-keterangan mengenai suatu subyek (pokok persoalan) atau pun peristiwa yang dibuat untuk membantu daya ingatan seseorang.

Berdasarkan beberapa pengertian tersebut arsip dapat diartikan sebagai bukti dalam sebuah kegiatan atau peristiwa yang dibuat oleh orang untuk membantu ingatan, yang biasanya dibuat dan diterima oleh instansi atau lembaga, baik pemerintahan atau lembaga swasta untuk menjalankan aktivitas organisasi.

Penyusutan Arsip merupakan kegiatan pengurangan arsip baik secara fisik maupun informasinya melalui proses pemindahan arsip dari unit pengolah/ kerja ke unit kearsipan, pemusnahan dan penyerahan arsip ke lembaga kearsipan. (Krihanta,2008).

Arsip yang akan disimpan adalah arsip yang memiliki nilai guna (Lolytasari,2015). Arsip tidak selamanya harus disimpan, suatu ketika (atas dasar umur arsip) arsip harus disusut dan dipindah dari tempat penyimpanan. Orang dapat membayangkan, bahwa suatu kantor pada suatu organisasi atau lembaga akan dipenuhi arsip pada suatu ketika apabila arsip-arsip harus disimpan terus. Dengan demikian tempat-tempat kegiatan akan didesak untuk penyimpanan arsip. Arsip memang tidak perlu disimpan terus, tetapi arsip juga tidak boleh terus dibuang atau disingkirkan begitu saja karena sudah terlalu banyak arsip di tempat penyimpanan.

Dalam pasal 2 Peraturan Pemerintah No. 34 tahun 1979 disebutkan, penyusutan arsip adalah kegiatan pengurangan arsip dengan cara berikut ini. 
1) Memindahkan arsip inaktif dan unit pengolah ke unit kearsipan dalam lingkungan lembagalembaga Negara atau Badan-badan Pemerintahan masing-masing.

2) Memusnahkan arsip sesuai dengan ketentuan-ketentuan yang berlaku untuk arsip yang sudah tidak memiliki nilai guna.

3) Menyerahkan arsip statis (arsip yang mempunyai nilai guna abadi) oleh unit kearsipan kepada Arsip Nasional atau Arsip Nasional Republik Indonesia.

Menyusutkan dan memindahkan arsip dari unit pengolah ke unit kearsipan perlu ditetapkan Angka Pemakaian suatu penyimpanan arsip. Arsip dalam penyimpanan perlu disusut dan dipindahkan apabila Angka Pemakaian menunjukkan angka batas atau di bawah batas yang seharusnya. Angka Pemakaian yang menunjukkan pada batas atau di bawah batas yang seharusnya, berarti arsip yang disimpan di unit pengolah sebagain besar merupakan arsip yang tidak memiliki nilai guna dan atau ada arsip yang memiliki nilai guna abadi yang harus diserahkan ke Lembaga Kearsipan (ANRI). Dengan demikian arsip yang disimpan di unit pengolah itu sebagian besar tidak berguna dan atau tidak memiliki kegunaan secara langsung untuk kegiatan lembaga atau organisasi yang bersangkutan. Apabila kondisi yang demikian tidak segera dibenahi (dilakukan penyusutan dan pemindahan) berarti pengelolaan arsip di unit pengolahan tidak efisien. Hal yang lebih parah dan ini banyak terjadi, baik di lembaga pemerintahan maupun swasta, yaitu tanpa dihitung Angka Pemakaiannya diadakan penyusutan dan pemindahan. Jadi, jelas tidak tepat mana arsip yang seharusnya disusut dan dipindahkan, mana arsip yang sebaiknya belum perlu disusut dan dipindahkan. Dengan menentukan Angka pemakaian suatu arsip, dapat ditetapkan perlu diadakan penyusutan dan pemindahan apabila Angka Pemakaiannya pada titik batas atau di bawah batas dan patokan yang ditetapkan (patokan kelayakan). Oleh karena itu (Mulyono:2012) menjelaskan lebih lanjut tentang Angka Pemakaian, maka selanjutnya akan dibahas hal-hal berikut ini:

Angka Pemakaian (AP) ialah angka perbandingan antara jumlah permintaan warkat (arsip) untuk dipakai kembali dengan jumlah warkat yang disimpan sebagai arsip dalam bentuk prosentase. Rumus Angka Pemakaian adalah sebagai berikut:

$$
A P=\frac{\sum \text { Permintaan Arsip }}{\sum \text { Arsip yang disimpan }} \times 100 \%
$$

Patokan kelayakan yang digunakan adalah apabila arsip aktif (arsip yang disimpan pada unit pengolahan) menunjukkan penggunaan arsipnya (AP) mencapai angka 15 sampai $20 \%$ (The Liang Gie, 1980: 237). Jadi, apabila diadakan uji kelayakan pada unit pengolah arsip suatu lembaga atau organisasi ternyata AP yang diperoleh $15 \%$ dapat ditetapkan perlu diadakan penyusutan dan 
pemindahan. Tentu saja sebaliknya, apabila uji kelayakan menunjukkan AP 30 \% (misalnya), penyusutan dan pemindahan belum perlu dilaksanakan.

Berikut di bawah ini contoh-contoh perhitungan AP dan tindakan yang harus dilakukan.

Arsip yang sudah tidak berguna memang seharusnya disusut dan dipindahkan dari unit pengolah arsip. Jangan lupa, bahwa diantara arsip yang disusut itu ada kemungkinan arsip yang harus disimpan terus atau dengan kata lain memiliki nilai guna abadi. Arsip yang memiliki nilai guna abadi dapat disimpan terus di lembaga atau organisasi yang bersangkutan selama nilai guna abadi tersebut tidak menyangkut "pelaksanaan kehidupan kebangsaaan" seperti yang tercantum pada pasal 1 ayat 2 UU No. 43 tahun 2009 tentang Kearsipan. Suatu hal yang perlu mendapat perhatian bagi organisasi swasta maupun perorangan yang memiliki arsip seperti yang dimaksud dalam pasal 1 ayat 2 UU No. 43 tahun 2009 dan pasal 62, pengelolaannya dilaksanakan berdasarkan asas asal usul dan asas aturan asli. Pengelolaan arsip statis (memiliki nilai abadi) seperti pada pasal tersebut di atas memang seharusnya dikelola (disimpan) di ANRI sesuai pasal 60 ayat 4 UU No. 43 tahun 2009.

Penyusunan jadwal retensi adalah suatu daftar yang memuat kebijaksanaan seberapa jauh sekelompok arsip dapat disimpan atau dimusnahkan (pasal 1 ayat 22 UU No. 43 tahun 2009). Dari daftar ini dapat diketahui tentang:

1) Lamanya masing-masing arsip disimpan pada file aktif (unit pengolah) sebelum dipindahkan ke tempat penyimpanan arsip (file inaktif).

2) Jangka waktu lamanya penyimpanan masing-masing atau sekelompok arsip sebelum dimusnahkan atau dipindahkan ke Lembaga Kearsipan (ANRI).

Siapa atau unit mana yang harus membuat Jadwal Retensi dari suatu organisasi, ini sangat penting untuk dikemukan sehingga tidak saling lempar tanggungjawab. Dalam kehidupan organisasi dapat dikatakan hampir semua unit kegiatan menghasilkan warkat atau record yang akan menjelma sebagai arsip. Arsip-arsip aktif dapat dikelola di masing-masing unit atau di pusatkan pada salah satu unit, tetapi arsip inaktif harus ditangani secara sentral. Jadi, suatu organisasi harus memiliki Pusat Penyimpanan Arsip Inaktif. Dengan demikian Jadwal Retensi harus dibuat oleh unit kearsipan dan dibuat secara rutin (dapat satu tahunan, dua tahunan atau periode tertentu). Dengan adanya Jadwal Retensi maka akan terlihat dengan jelas bahwa arsip aktif tidak akan tersimpan bersama-sama dengan arsip inaktif. Hal ini memudahkan pengelolaan baik arsip aktif maupun arsip inaktif, sehingga penyusutan dan pemindahan arsip dapat berjalan sebagai mana mestinya. Peristiwa yang sangat menggangu dan merugikan adalah “tidak mudah menemukan kembali” arsip yang diperlukan, karena ketidakteraturan dalam penyimpanan atau arsip yang dimaksud terlanjur dihapuskan. Jelas tidak efisien apabila arsip yang disimpan jumlahnya banyak dan dan jumlah itu sebagian besar justru arsip yang sudah tidak berguna atau tidak secara langsung memiliki kegunaan. Suatu organisasi tidak perlu 
menyimpan sendiri arsip-arsip bernilai abadi sepanjang arsip tersebut memiliki kegunaan dalam rangka pelaksanaan kehidupan kebangasan. Arsip tentang "Nitisemito" seorang pengusaha rokok dari Kudus yang hidup pada zaman kolonial meskipun tidak lengkap tetap tersimpan pada ANRI. Demikian pula mestinya arsip perseorangan seperti "Tasripin” dan "Oei Tiongham” yang memiliki nilai sejarah, khususnya Kota Semarang perlu disimpan di Lembaga Kearsipan (ANRI).

Membuat Jadwal Retensi berarti menentukan kebijakan dalam menilai suatu arsip, baik atas dasar jenisnya, fisiknya maupun informasinya. Dari ketiga dasar penilaian ini yang paling esensial adalah penilaian atas dasar informasi yang terkandung di dalam arsip yang bersangkutan. Dengan adanya informasi yang diperoleh dari arsip itu, maka dapat ditentukan nilai kegunaannya. Penetapan jangka waktu penyimpanan didasarkan atas nilai guna arsip tersebut. Penyusutan dan pemindahan arsip dapat dilakukan atas dasar jangka waktu penyimpanan.

Arsip yang disimpan di unit pengolah maupun di tempat penyimpanan arsip inaktif sifatnya sementara, artinya arsip-arsip itu tidak selamanya disimpan di tempat penyimpanan. Selama pembuatan jadwal retensi secara kontinyu dikerjakan, maka tempat penyimpanan arsip akan selalu teratur atau setidak-tidaknya tidak akan terjadi kehilangan arsip atau tercecernya arsip. Apabila jadwal retensi secara teratur dikerjakan, maka arsip akan mengalir dari unit pengolah ke tempat penyimpanan arsip inaktif dan selanjutnya dilakukan penghapusan bagi arsip yang sudah tidak memiliki nilai guna lagi.

Kapan arsip dipindahkan dari suatu tempat ke tempat lain, yaitu dari unit pengolah ke gudang penyimpanan dan dari gudang penyimpanan ke tempat penghapusan arsip, atau ke tempat penyimpanan tetap (bagi yang bernilai guna abadi) atau Lembaga Kearsipan (ANRI). Waktu yang yang paling tepat untuk menyusut dan memindahkan arsip adalah akhir tahun. Kalau dapat dilakukan pada setiap akhir tahun, tentu akan sangat tepat, tetapi apabila tidak dapat diatur pemindahan arsip itu pada akhir tahun dalam jangka waktu tertentu (misalnya setiap 2 tahun atau setiap 3 tahun, átau mungkin setiap 5 tahun). Banyak lembaga atau organisasi baik pemerintah maupun swasta "kurang memperhatikan" pengelolaan arsipnya. Penyusutan dan pemindahan arsip tidak teratur, bahkan cenderung tanpa jadwal retensi arsip-arsip yang sudah lama (menurut perkiraan mereka) langsung dihapus. Dengan demikian tidak memperhatikan berapa lama seharusnya arsip tersebut perlu disimpan.

Untuk lembaga-lembaga pemerintah pada tingkat kabupaten, propinsi dan pemerintah pusat mengalirnya pemindahan arsip dapat dijelaskan sebagai berikut ini.

1) Semua warkat yang masuk dan keluar pada suatu lembaga atau organisasi merupakan bahan arsip, artinya warkat tersebut setelah selesai akan disimpan sebagai arsip. 
2) Mulai warkat masuk atau keluar seharusnya dikelompokkan apakah warkat-warkat itu termasuk warkat Tidak penting (diberi kode T), warkat Biasa (diberi kode B), warkat Penting (diberi kode P), dan warkat sangat penting atau Vital (diberi kode V).

3) Dari penggolongan warkat dengan kode T, B, P, dan V akan diketahui seberapa lama warkat akan disimpan sebagai arsip.

4) Ada warkat yang hanya disimpan dalam waktu singkat (kurang dari 1 tahun), ada yang harus disimpan 1-5 tahun, ada yang harus disimpan 5-10 tahun, dan bahkan ada yang harus disimpan secara abadi.

Proses selanjutnya dalam pemindahan arsip didasarkan atas lamanya arsip perlu disimpan. Hal ini diperkirakan pemindahan arsip dari suatu tempat penyimpanan ke tempat penyimpanan yang lain untuk diproses penyusutannya dapat dilihat pada bagan di bawah ini:

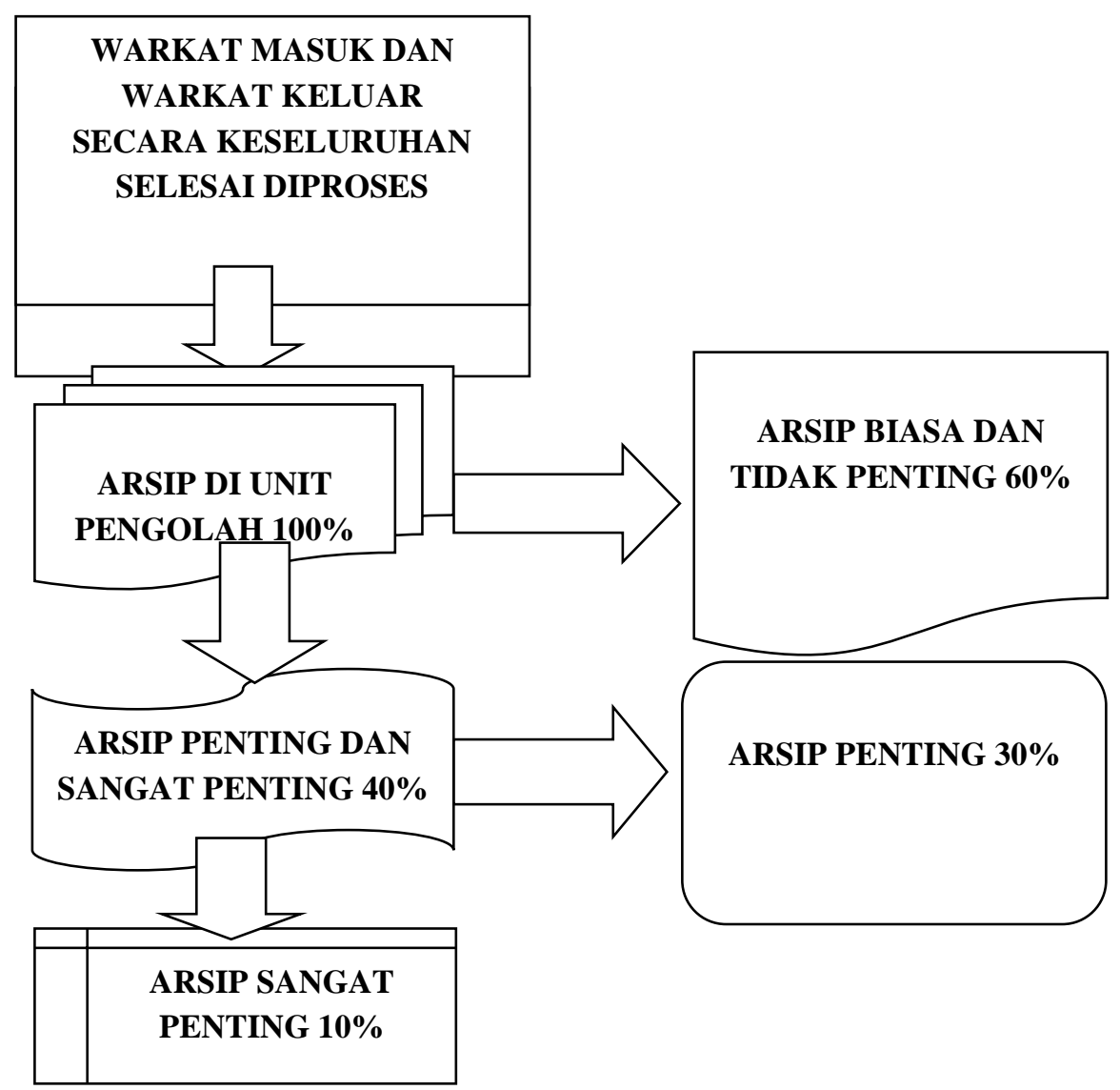

\section{Bagan Pemindahan Arsip}

Keterangan:

1) Semua warkat yang sudah selesai diproses diberi tanda pembebas dan selanjutnya disimpan sebagai arsip.

2) Sebagai arsip di unit pengolah sebagian besar kurang lebib $60 \%$ segera disusut dan dipindahkan ke tempat penyimpanan arsip inaktif

3) Selanjutnya yang $40 \%$ akan tetap di unit pengolah sebagai arsip aktif artinya masih digunakan dalam penyelengaraan aktivitas organiasi secara langsung.

4) Dari jumlah $40 \%$ arsip aktif sebanyak kurang lebih $30 \%$ merupakan arsip penting yang secara langsung masih digunakan dalam kegiatan organisasi. Sedang sisanya $10 \%$ merupakan arsip yang sangat panting (arsip statis).

5) Dan arsip statis ini sebagian atau seluruhnya dapat dikirim ke Lembaga Kearsipan. Apabila dari arsip statis ini tidak ada yang memiliki kegunaan secara nasional, maka arsip ini harus disimpan secara abadi oleh organisasi yang bersangkutan. 
Perhitungan di atas sebagian basar berlaku untuk lembaga-lembaga pemerintah sedangkan untuk organisasi swasta atau perorangan pembagian seperti tersebut di atas tidak berlaku. Terutama pada $10 \%$ arsip statis ada kemungkinan angkanya tidak sampal $1 \%$ bahkan dapat $0 \%$. Hal yang demikian dapat terjadi karena arsip-arsip pihak swasta atau perorangan sangat kecil kemungkinan memiliki arsip yang bernilai guna secara nasional. Tentu saja hal itu tidak menutup kemungkinan bahwa arsiparsip statis dari pihak organisasi swasta maupun arsip perorangan mempunyai nilai guna secara nasional. Dalam hal ini dapat terjadi adanya arsip dari organisasi swasta tentang penemuan-penemuan yang bersifat ilmiah atau rekayasa teknologi. Sedangkan arsip-arsip perorangan ada kemungkinan memiliki nilai sejarah baik yang bersifat regional maupun nasional.

\section{METODE}

Metode yang digunakan dalam penelitian ini adalah studi kasus, dimana menurut Creswell (2010) peneliti menyelidiki secara cermat suatu program, peristiwa, aktivitas, proses atau sekelompok individu. Informan dalam penelitian ini adalah pihak-pihak yang bertanggung jawab dalam pengelola arsip di lingkungan Universitas Negeri Semarang. Pemilihan informan ini akan memudahkan peneliti dalam meneliti objek yang diteliti dan dianggap mengetahui masalah yang diteliti atau orang yang terlibat dalam penyusutan arsip perguruan tinggi, sehingga diperoleh informasi mengenai teknik penyelamatan arsip yang tercipta.

Prosedur pengumpulan data dalam penelitian ini, diantaranya adalah dengan metode observasi, wawancara tidak terstruktur dan pengambilan dokumen. Keabsahan data dapat dicapai dengan proses pengumpulan data yang tepat. Dalam penelitian ini pengujian dilakukan dengan proses triangulasi, yaitu teknik pemeriksaan keabsahan data yang memanfaatkan sesuatu yang lain di luar data itu untuk keperluan pengecekan atau sebagai pembanding terhadap data itu.

\section{HASIL DAN PEMBAHASAN}

Penyusutan Arsip Secara Peraturan Perundang-Undangan di Universitas Negeri Semarang. Penyusutan arsip di Universitas Negeri Semarang dilakukan karena volume arsip yang terus bertambah dari waktu ke waktu. Universitas Negeri Semarang menjalankan tugas administrasi untuk memperlancar kegiatan akademik jumlah arsip yang dihasilkan jumlahnya cukup banyak, mulai dari kegiatan akademik, kemahasiswaan, kepegawaian, pengelolaan sarana dan prasarana, penelitian dan pengabdian.

Berdasarkan hasil penelitian yang diperoleh dari wawancara, observai dan dokumentasi dari Kepala UPT Kearsipan Universitas Negeri Semarang, Ka BUHK dan Kabag Umum Universitas Negeri Semarang untuk penyusutan arsip di lingkungan Universitas Negeri Semarang menggunakan 
prosedur penyusutan arsip menurut UU No. 43 Tahun 2009 Tentang Kearsipan, diantaranya (a) Pemindahan Arsip Inaktif dari unit pengolah ke unit kearsipan. (b) Pemusnahan arsip yang telah habis masa retensinya dan tidak memiliki nilai guna dilaksanakan sesuai dengan ketentuan peraturan perundang-undangan. (c) Penyerahan arsip statis oleh pencipta arsip kepada lembaga kearsipan

Penyusutan arsip dilakukan Unit Kerja atau unit pencipta arsip dengan tujuan penyusutan arsip adalah untuk Efisiensi dan efektifitas kerja, enyelamatan informasi dari pihak yang tidak berhak untuk mengetahuinya, dan mengurangi volume arsip yang tersimpan pada setiap unit kerja/ pencipta arsip.

Prosedur dalam penyusutan arsip meliputi : (a) Prosedur Pemindahan Arsip Inaktif. (b) Prosedur Pemusnahan Arsip. (c) Prosedur Penyerahan Arsip ke Lembaga Kearsipan (UPT Kearsipan).

Pertama, Prosedur Pemindahan Arsip dilakukan melalui pemeriksaan arsip terlebih dahulu yang selanjutnya dilakukan pembuatan daftar arsip inaktif, penataan arsip, pembuatan berita acara pemindahan arsip, dan pelaksanaan pemindahan arsip.

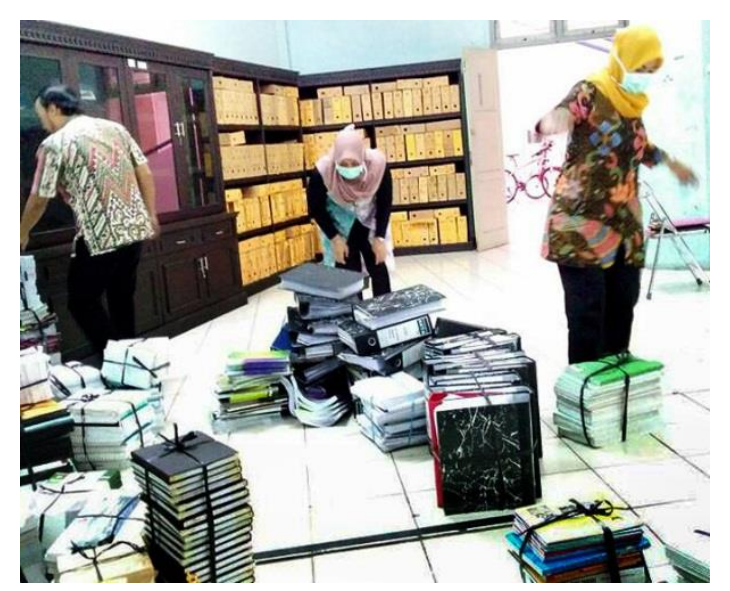

Penataan Arsip

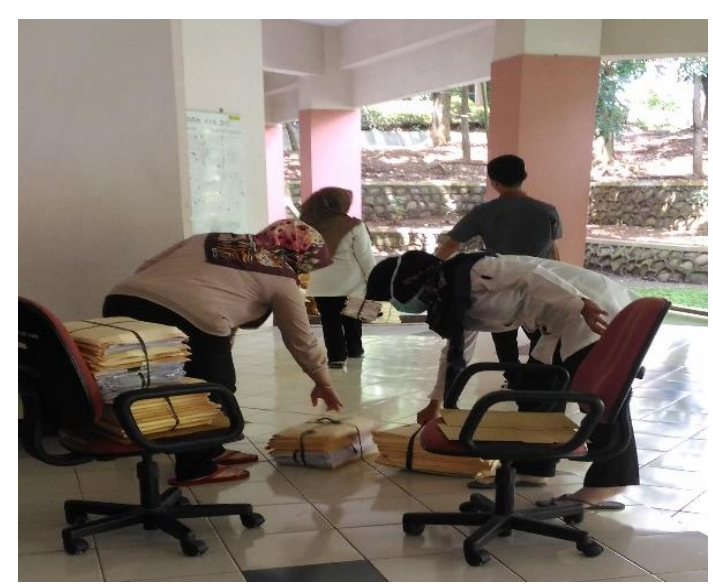

Pemindahan Arsip

Gambar1. Pemindahan Arsip Inaktif

Kedua, kegiata penyusutan arsip yang selanjutnya adalah dilakukannya kegiatan pemusnahan. Dalam kegiatan pemusnahan dilakukan beberapa prosedur pemusnahan arsip yaitu dengan cara dilakukan pemeriksaan, pebuatan daftar arsip yang akan dimusnahkan, pembentukan panitia pemusnahan, penilaian persetujuan dan pengesahan, pembuatan berita acara pemusnahan arsip, dan yang terakhir adalah pelaksanaan pemusnahan arsip. 


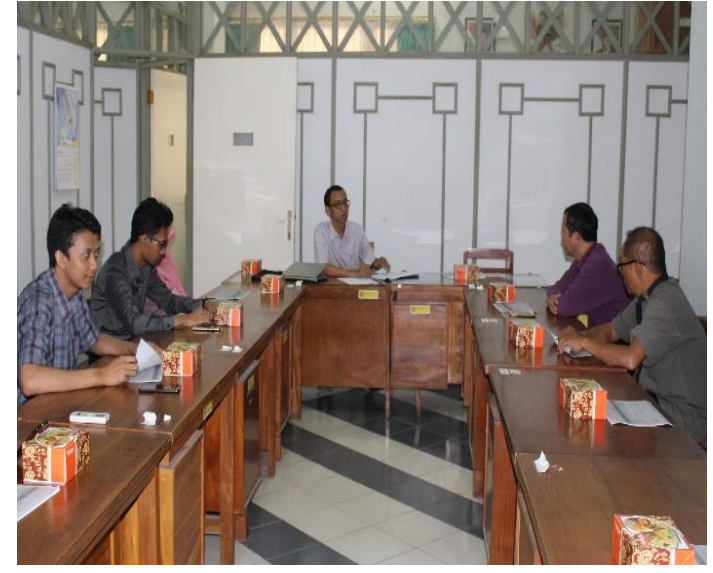

Pembentukan Panitia Pemusnahan Arsip

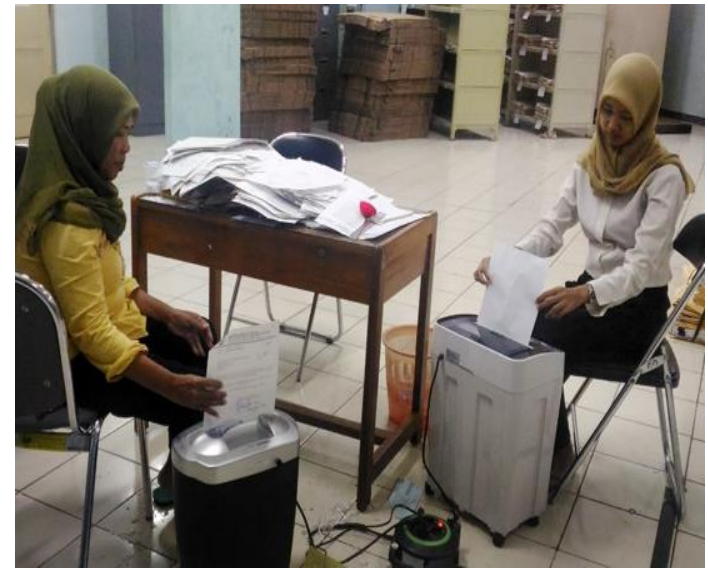

Pemusnahan Arsip

Gambar 2. Pemusnahan Arsip

Ketiga, prosedur penyusutan arsip selanjutnya adalah penyerahan arsip ke Unit Pelaksana Teknis (UPT) kearsipan Universitas negeri semarang yang di dalamnya meliputi kegiatan pemeriksaan dan penilaian arsip, pendaftaran arsip yang akan diserahkan UPT, pembuatan berita acara penyerahan, dan pelaksanaan penyerahan arsip ke Unit Pelaksana Teknis (UPT).

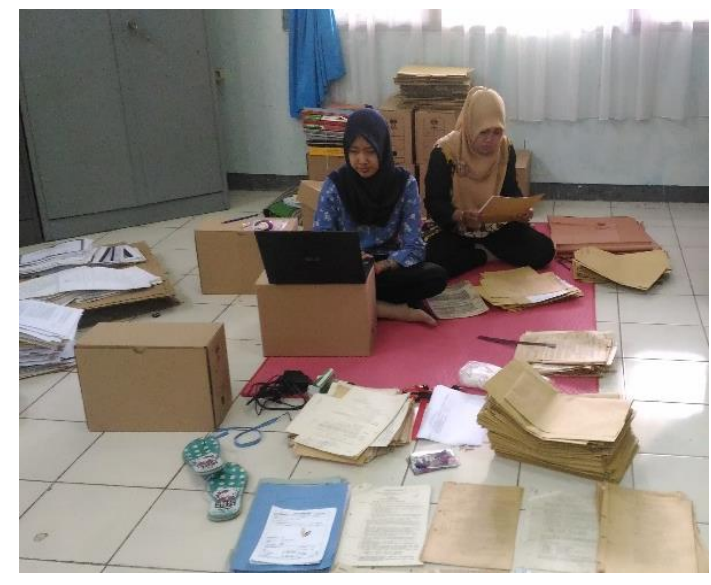

Pendaftaran Arsip

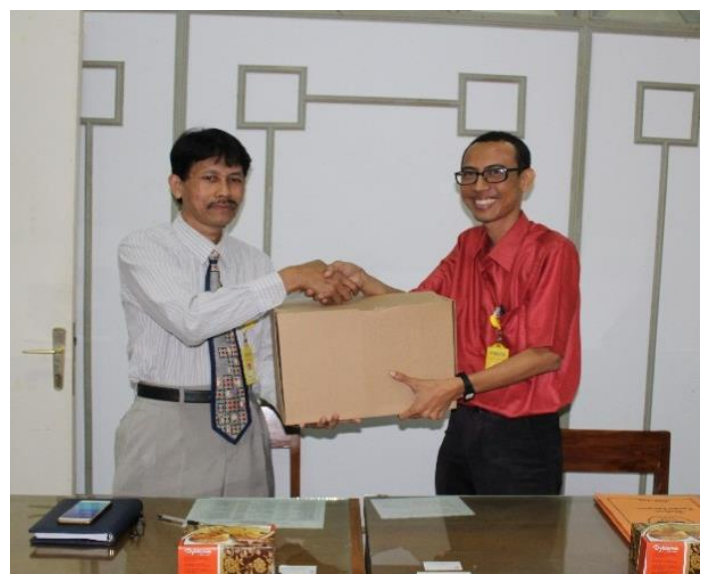

Pemusnahan Arsip

Gambar 3. Penyerahan Arsip ke Lembaga Kearsipan (UPT Kearsipan)

Cara penyusutan arsip di Universitas Negeri Semarang. Cara yang dilakukan penyusutan arsip di Universitas Negeri Semarang meliputi: (a) Pembuatan Daftar Pertelaan Arsip, (b) Pemindahan arsip inaktif ke unit kearsipan, (c) Pemusnahan arsip inaktif di masing-masing unit kerja dan disaksikan oleh pimpinan dan para saksi dari unit kerja terkait. (d) Penyerahan arsip statis ke UPT Kearsipan Universitas Negeri Semarang.

Cara pemindahan/ akuisisi arsip di Universitas Negeri Semarang; (a) Penyeleksian arsip inaktif, (b) Pembuatan daftar arsip yang akan dipindahkan, (c)Penataan fisik arsip yang akan dipindahkan, 
(d) Serah terima arsip inaktif dari unit kerja ke Pusat Arsip dengan penandatanganan berita acara pemindahan arsip inaktif.

Tahapan kegiatan pemusnahan arsip adalah sebagai berikut: (a) Pemeriksaan Pemeriksaan dilaksanakan untuk mengetahui apakah arsip-arsip tersebut benar-benar telah habis jangka simpannya atau habis nilaigunanya. Pemeriksaan ini berpedoman kepada Jadwal Retensi Arsip (JRA). (b) Pendaftaran Arsip-arsip yang telah diperiksa sebagai arsip yang diusulkan musnah, harus dibuat daftarnya. Dari daftar ini diketahui secara jelas informasi tentang arsip-arsip yang akan dimusnahkan. (c)Pembentukan Panitia Pemusnahan Jika arsip yang akan dimusnahkan memiliki retensi di bawah 10 tahun atau lebih, maka perlu membentuk panitia pemusnahan. Jika arsip yang akan dimusnahkan memiliki retensi di bawah 10 tahun, maka tidak perlu dibuat kepanitiaan, tetapi cukup dilaksanakan oleh unit yang secara fungsional bertugas mengelola arsip.(d) Penilaian, Persetujuan dan Pengesahan Setiap menyeleksi arsip yang akan dimusnahkan, perlu melakukan penilaian arsip. Hasil penilaian tersebut menjadi dasar usulan pemusnahan. Pelaksanaan pemusnahan harus ditetapkan dengan keputusan pimpinan instansi yang bersangkutan sesuai dengan ketentuan hokum yang berlaku. (e) Pembuatan Berita Acara Berita acara pemusnahan arsip merupakan salah satu dokumen pemusnahan arsip yang sangat penting. Karena itu setiap pemusnahan arsip harus dilengkapi dengan Daftar Pertelaan Arsip (DPA) dan Berita Acara (BA), bahwa pelaksanaan pemusnahan dilakukan secara sah. Selain itu, juga berfungsi sebagai pengganti arsip yang dimusnahkan. (f) Pelaksanaan pemusnahan arsip di Universitas Negeri Semarang dilakukan dengan menggunakan alat pencacah kertas (paper shrider)

Pemindahan arsip yang dilakukan adalah dengan cara penyerahan arsip dari unit kerja ke lembaga kearsipan Universitas Negeri Semarang meliputi (a) Melalukan pemeriksaan dan penilaian arsip yang akan diserahkan, (b) Pembuatan Daftar Arsip yang akan diserahkan ke UPT Kearsipan, (c) Pembuatan berita acara serah terima arsip, (d) Pelaksanaan penyerahan arsip

Prosedur penyusutan arsip di Universitas Negeri Semarang. Prosedur penyusutan arsip di Universitas Negeri Semarang adalah Pembuatan Daftar Pertelaan Arsip, Pemindahan Arsip, Pemusnahan Arsip yang sudah tidak bernilai guna, dan Penyerahan arsip ke UPT Kearsipan yang bernilai guna permanen/ sejarah.

Sejauh ini, unit-unit kerja ada yang sudah melaksanakan penyusutan arsip. Diantaranya BUHK, BAKK, dan BPK. Unit kerja dapat melaksanakan penyusutan arsip jika memiliki daftar arsip yang akan disusutkan yang telah habis masa retensinya atau tidak bernilai guna permanen. Dalam menentukan retensi arsip dapat melihat Pedoman Jadwal Retensi Arsip. 
Arsip yang akan disusutkan terlebih dahulu diusulan kepada petugas atau arsiparis yang menangani arsip secara langsung dan mengajukan penyusutan kepada pimpinan terkait untuk selanjutnya ditindak lanjuti.

Penyusutan arsip yang dilakukan di UPT Kearsipan Universitas Negeri Semarang harus memenuhi syarat-syarat penyusutan antara lain (a) Tidak memiliki nilai guna, (b) Telah habis retensi dan berketerangan dimusnahkan berdasarkan JRA, (c) Tidak ada peraturan perundang-undangan yang melarang, (d) Tidak berkaitan dengan penyelesaian proses suatu perkara.

Berkas-berkas yang dipersiapkan dalam penyusutan arsip di Universitas Negeri Semarang (a) Daftar Pertelaan Arsip, (b) Berita Acara Penyusutan Arsip

Sarana dan prasarana yang digunakan dalam penyusutan arsip di lingkungan Universitas Negeri Semarang dengan alat pencacah kertas, masker, karung (kantong plastic besar), gunting dan ruang khusus untuk kegiatan pencacahan karena berdebu.

\section{KESIMPULAN}

Penyusutan arsip di lingkungan Universitas Negeri Semarang menggunakan prosedur penyusutan arsip menurut UU No. 43 Tahun 2009 Tentang Kearsipan, diantaranya (a) Pemindahan Arsip Inaktif dari unit pengolah ke unit kearsipan. (b) Pemusnahan arsip yang telah habis masa retensinya dan tidak memiliki nilai guna dilaksanakan sesuai dengan ketentuan peraturan perundangundangan. (c) Penyerahan arsip statis oleh pencipta arsip kepada lembaga kearsipan.

Cara penyerahan arsip dari unit kerja ke lembaga kearsipan Universitas Negeri Semarang meliputi (a) Melalukan pemeriksaan dan penilaian arsip yang akan diserahkan, (b) Pembuatan Daftar Arsip yang akan diserahkan ke UPT Kearsipan, (c) Pembuatan berita acara serah terima arsip, (d) Pelaksanaan penyerahan arsip.

Prosedur penyusutan arsip di Universitas Negeri Semarang adalah Pembuatan Daftar Pertelaan Arsip, Pemindahan Arsip, Pemusnahan Arsip yang sudah tidak bernilai guna, dan Penyerahan arsip ke UPT Kearsipan yang bernilai guna permanen/ sejarah.

\section{DAFTAR PUSTAKA}

Amsyah, Zulkifli. 2003. Manajemen Kearsipan. Jakarta: PT Gramedia Pustakan Utama

Annisa, Iftah Fitri dan Marlini. (2013). Penyusutan dan Nilai Gua Arsip di Unit Kearsipan Dinas Prasarana Jalan, Tat Ruang dan Permukiman Provinsi Sumatera Barat. Jurnal Ilmu Informasi Perpustakaan dan Kearsipan.Vol. 2. No. 1 Hlm. 323-330.

Barthos, Basir. 2007. Manajemen Kearsipan. Jakarta: Bumi Aksara 
Creswell, J. W. (2010). Research Design Pendekatan Kualitatif, Kuantitatif, dan Mixed Edisi Ke-3. Yogyakarta: Pustaka Pelajar.

Irawan, Mustari. 2009. Perancangan Jadwal Retensi Arsip. Jakarta: Universitas Terbuka.

Krihanta. (2008). Akreditasi Lembaga Kearsipan Provinsi dalam Rangka Meningkatkan Layanan kepada Masyarakat. Jurnal Kersipan.Vol. 3 Hlm. 32-83.

Lolytasari. (2015). Penyusutan Arsip Perguruan Tinggi dalam Upaya Penyelamatan Arsip. Record And Library Journal.Vol.1. No. 1 Hlm. 26-38.

Mulyono, Sularso, Partono dan Agung Kuswantoro.2012. Manajemen Kearispan. Semarang: UNNES Press.

Peraturan Pemerintah No. 24 Tahun 1979 tentang Penyusutan Arsip

Sudjono, dkk. 2007. Penilaian dan Penyusutan Arsip. Jakarta: Universitas Terbuka.

Sulistyo, Basuki.1996. Pengantar Kearsipan. Jakarta: Universitas terbuka.

Undang-undang Pasal 1 Ayat 2 No. 43 Tahun 2009 tentang Peyusutan Arsip.

Undang-undang Pasal 26 No. 43 Tahun 2009 tentang Peyusutan Arsip.

Undang-undang Pasal 60 Ayat 4 No. 43 Tahun 2009 tentang Peyusutan Arsip.

Widodo, P. Bambang. 2009. Akuisisi Arsip. Jakarta: Universitas Terbuka.

\section{UCAPAN TERIMA KASIH}

Pada bagian ucapan terima kasih dituliskan ucapan terima kasih kepada pihak-pihak yang telah berkontribusi pada semua proses pelaksanaan penelitian dan penerbitan artikel ini.

\section{PROFIL PENULIS}

Penulis merupakan dosen di Program Studi Pendidikan Administrasi Perkantoran Universitas Negeri Semarang. 